Borneo Journal of Social Science and Humanities

DOI: https://doi.org/10.35370/bjssh.2020.2.1-03

e-ISSN: 2682 - 8235

(C) 2018, UCTS Publisher.

Submitted: 2 April 2020

Accepted: 12 May 2020

Published: 30 June 2020

\title{
Why Locals Consume Less Their Natural Honey? Evidence from Penang, Malaysia
}

\author{
Lim Ghee-Thean ${ }^{1 *}$, Jacqueline Liza Fernandez ${ }^{2}$ and Mohd Mansor Ismail ${ }^{3}$ \\ ${ }^{1 \& 2}$ School of social Sciences, Universiti Sains Malaysia, Malaysia \\ ${ }^{3}$ Institute of Agricultural and Food Policy Studies, Universiti Putra Malaysia, Malaysia \\ *Corresponding author: limgheethean@usm.my
}

\begin{abstract}
Honey is a common food in Malaysia and consumed primarily for its nutritional benefits and as a preventative treatment. However, Malaysians seem to prefer the consumption of imported honey. The local honey industry can be invigorated if Malaysians are willing to consume more locally produced honey. This study attempts to examine the factors affecting the decision to purchase local natural honey by using a probit model. Besides the general socio-economic factors, an analysis of product-related factors is of importance to understand the choice made by consumers. Results indicate that factors such as stock availability and distribution availability of honey, packaging, consumers' income, and educational background influence the purchasing decision of consumers towards local honey.
\end{abstract}

Keywords: Local honey; Malaysia; Probit model; Product-related factors; Purchasing decision; Theory of Planned Behaviour (TPB).

\section{Introduction}

What is honey? The web page of Speckman honey provides an apt description of honey, i.e. "Honey gets its start as flower nectar, which is collected by bees, naturally broken down into simple sugars and stored in honeycombs. The unique design of the honeycomb, coupled with constant fanning by the bees' wings, causes evaporation to take place, creating the thick, sweet liquid call as honey". Malaysia's tropical rainforest is endowed with an abundance of countless plant species producing nectar and pollen for bees. For this reason, Malaysia has numerous bee species. With these endowments, there is a great potential for the Malaysian local honey industry to be developed, especially the beekeeping industry. Malaysian beekeeping comprises apiculture (beekeeping with honeybees) and meliponiculture (beekeeping with stingless bees). The Malaysian government has identified the beekeeping industry as a potential industry to be developed in the agricultural policy.

Malaysian Agricultural Research and Development Institute (MARDI) has listed stingless bee honey as a Malaysian superfood. Superfood refers to all kinds of nutrient-rich food that contains vitamins, minerals, antioxidant enzymes and others (The Star, 2016). Under the MARDI program of superfood, stingless bee honey is targeted in the nation's agricultural development. Despite the government's support in stingless bee honey farming, apiculture honey-like Acacia honey and pineapple honey are popular products selling in the Malaysian local honey market as well as overseas markets. Besides honey produced from beekeeping activity, honey is also harvested from the forest to supply the local market demand. Local honey in this study refers to the honey produced from these two activities (harvesting and beekeeping). Despite a bright future for the Malaysian local honey industry and the great support from the Malaysian government, yet this industry faces a lot of challenges that hamper its growth. Local 
Borneo Journal of Social Science \& Humanities

DOI:

e-ISSN: $2682-8235$

(C) 2018, UCTS Publisher.

Submitted: 2 April 2020

Accepted: 12 May 2020

Published: 30 June 2020

honey consumption is relatively low compared to imported honey. The total import of honey (3,668 tonnes) was much greater than the total export of Malaysian honey (470 tonnes) in 2016 (FAOSTAT, 2019). The honey trade deficit of Malaysia leads to capital outflow from Malaysia to other countries and this, in turn, contributes to the food deficit in the balance of payments. Also, these incidents are not in line with the Malaysian Department of Agriculture (DOA) food security policy and "beli barangan buatan Malaysia (buy Malaysia products)" campaign. How could these have happened? The low local honey consumption could be attributed to the lack of support to the local community that mentioned in the previous study (Arsil, Li \& Bruwer, 2016) and also poor marketing. Consumers may be facing various challenges in purchasing local honey and these may contribute directly and indirectly to low consumption of local honey. Lack of local honey supply and marketing channels for customers as well as making sales by word of mouth continue to hinder growth of the local honey industry (Ismail, 2012). Besides, price competition with imported honey leads to low price of honey for beekeepers thereby making it difficult for small scale beekeepers to expand their bee farms. There is a study about consumers' intention to purchase honey related products in Malaysia (Yeow et al., 2013).

However, their research is not limited to local honey (but also includes imported honey) and thus the outcome of the study explores the general perception of consumers on honey related products; therefore, the research findings do not really benefit the local honey industry in terms of understanding the weaknesses or factors responsible for the low local honey consumption. To the best of our knowledge, no study analyses the influence of product-related and socio-economic factors on consumers in this promising industry (local honey). An analysis of product-related factors can be used to outline strategies that can increase the sale of local honey of small-scale beekeepers (that account for most beekeepers) and enhance their revenue by tapping the domestic market. Hence, examining these factors is of importance to guide the authorities, investors and beekeepers in developing the local honey industry. The issue of low consumption of local honey needs to be addressed so that the local honey industry can realize its potential. Examining factors (especially product-related factors) affecting the local honey purchasing decision of Malaysians is of paramount importance for developing a growing local honey domestic consumption trend. The objective of this study is to examine the impact of socio-economic and product-related factors on the decision to purchase local honey using a probit regression model.

\section{Literature Review}

Theory of Planned Behaviour, TPB (an extension of Theory of Reasoned Action) (Ajzen, 1991) is widely employed in social science research to examines an exercised human behaviour. TPB offers a framework that investigates the independent variables scientifically affecting behaviour choices. Attitude, subjective norm and perceived behaviour control are the three main components of the intention of a behaviour (Park, 2000). The definition of attitude, "the degree to which a person has favourable or unfavourable evaluation or appraisal of the behaviour in question" is widely referred (Ajzen, 1991). Attitude could be developed by a person's experience, culture, religious behaviour and ways of living over a lifetime. On the other hand, the subjective norm could be understood as ideas or opinions or strategies that influence a person to perform a certain behaviour (Ajzen, 1991). It is a normative belief that how a person should or should not behave. Perceived behavioural control refers to factors (internal or external) that influence a person's behaviour being performed easily or laboriously 
Borneo Journal of Social Science \& Humanities

DOI:

e-ISSN: $2682-8235$

(C) 2018, UCTS Publisher.

Submitted: 2 April 2020

Accepted: 12 May 2020

Published: 30 June 2020

(Ajzen \& Madden, 1986). Several similar studies on honey products have been conducted in various countries such as Malaysia, Thailand, Indonesia, China, Australia, New Zealand, United States, Nigeria, Romania and others. From the previous studies, there are several classical factors frequently applied in the analysis of honey purchasing behaviour. This study views the factors as two major groups, namely socio-economic and product-related variables. Consumer's age, educational background, income, household size and consumption pattern are among the main socio-economic variables frequently studied. Product-related variables refer to the variables developed from the concept of TPB and the term of marketing factors is used in previous studies. Product-related factors consist of price, packaging, advertisement, distribution availability, stock availability, certification, company reputation, medical effect and knowledge on local honey.

\section{Socio-economic variables}

Among the socio-economic background variables, age is one of the factors commonly used by researchers. The findings on this factor are inconsistent in different countries. Young Romanian consumers are indifferent towards honey and thus less likely to consume honey (Arvanitoyannis \& Krystallis, 2006). However, the research found that Romanian elderly (61 years and over) are not honey consumers and honey is bought by Romanians in the median age category which consists of individuals 26 to 50 years old (Pocol, 2011, 2012). Also, most honey consumers in the state of Kerala, India are between 20 to 29 years old (Santhosh \& Varghese, 2015). However, Vojvodina's population over the age of 50 is a very important segment of loyal customers of honey (Ciric, Ignjatijevic \& Cvijanovic, 2015).

The educational background of consumers is playing a significant role in affecting honey purchasing behaviour. Studies showed that employee, employer or self-employed with higher education could contribute more to honey purchasing compared to other income levels of a community (Pocol, 2011, 2012; Pocol \& Bolboaca, 2013). Furthermore, some studies even highlighted that honey purchasing activity is dominated by those with university education and above (Ciric, Ignjatijevic \& Cvijanovic, 2015; Santhosh \& Varghese, 2015).

Consumer decision to consume honey is also influenced by economic status or financial situation (ex: income level) of households (Roman, Popiela-Pleban \& Kozak, 2013). Pocol (2011) stated that individuals who consume honey frequently belong to the medium-high expenses category in her analysis of the association between the amount of household monthly expenditure and honey consumption. Those in the category of low expenses, as well as very high expenses, rarely consume honey. Yet, a research indicated that increases in income level explain the dramatic increase in the market demand for honey (Ismaiel et al., 2014).

Ciric, Ignjatijevic \& Cvijanovic (2015) implied that three and four members households dominate the purchase of honey. While Pocol \& Marghitas (2007) found that households with children contribute more towards the number of purchasing honey.

\section{Product-related variables}

Another set of factors that influence the purchase of honey is product-related factors. Pocol \& Marghitas (2007) realized the health benefit effect of honey plays a role in influencing the purchase of honey. They mentioned that consumers respond positively to the following attributes: honey is a natural product (it is healthy). Honey is perceived to be a delicious product, delightful to consume and is considered a panacea, a product offering a rich set of benefits 
Borneo Journal of Social Science \& Humanities

DOI:

e-ISSN: $2682-8235$

(C) 2018, UCTS Publisher.

Submitted: 2 April 2020

Accepted: 12 May 2020

Published: 30 June 2020

satisfying many needs especially those concerning health (Pocol \& Marghitas, 2007; Pocol \& Bolboacă, 2013; Roman et al., 2013)

By increasing the production of honey, the expansion of distribution channels must be considered (Ciric, Ignjatijevic \& Cvijanovic, 2015). Distribution availability (as one of the proxies of perceived behaviour control) should be concerned by the market players because the ideal selling points can enhance the sales of honey. Consumer convenience can be measured by the ease of purchasing the product, finding the product, finding information about the product and several other factors. People decide in favour of buying based on convenience, i.e. when. consumers can easily find their desired product at any time and anywhere. Ványi, Csapó \& Kárpáti (2011) found that most consumers purchase honey only a few times per year, or monthly and mainly in hypermarkets or directly from the producer. Buying honey directly from the beekeeper is widespread among consumers but the supermarket is the primary place of purchase (Cosmina et al., 2016).

Availability of stock (as one of the proxies of perceived behaviour control) is the practice whereby a business holds products in reserve to safeguard against any unforeseen shortages or product demands. Having no stock is unacceptable by consumers and it shows disability of business to align supply with consumer demand. This will cause loss of intended purchase when customers encounter suppliers that have run out of stock. To avoid this problem, most consumers would prefer to purchase honey directly from producers (Ismaiel et al., 2014).

Price is an important factor (as one of the proxies of perceived behaviour control) that determines whether consumers will purchase a product. Price is an important consideration for those with a limited budget. Generally, consumers may look for lower price products to save their expenses. Hence, higher price products are more vulnerable to competitors because consumers prefer lower price products, assuming other factors remain constant. Yeow et al. (2013) opined that price is one of the important factors influencing the purchase of honey related products. Santhosh \& Varghese (2015) also revealed that price discount and quality of the product can increase the quantity of the honey to be purchased. Older people mainly consider price as an important determinant in their decision to purchase honey. Furthermore, factors related to price discount could mostly motivate people to buy more honey (Ványi, Csapó \& Kárpáti, 2011).

Consumer engagement is a vital part of any business. Communication channels (as a proxy of the subjective norm) consist of door-to-door sales, word of mouth (family, relatives, friends and others), advertising and so on. These can attract potential consumers and retain existing customers. Promotion of honey using a simple newsletter, an e-mail update, or social media would expose consumers to honey. Such promotions can eventually lead to an increase in demand (Pocol \& Marghitas, 2007; Santhosh \& Varghese, 2015). Cosmina et al. (2016) argued that value-added in the production method might not be perceived by consumers if it is not conveyed to consumers via suitable communication channels. In addition, developing brand-personality differences is of importance and should be focused by Malaysian local producers (Hashim, Shah \& Omar, 2018). Negara and Dharmmesta (2003) highlighted that consumers could remember instantly the products or the brands of particular products when they are shopping and thereby encourage unplanned purchasing. Multiple celebrity endorsements will also generate a better consumer's attitude towards the product and the brand of product (like Malaysian local honey) (Handriana \& Wisandiko, 2017). This study believes that through marketing campaigns, local honey producers can address the distinction between imported honey and original local honey. 
Borneo Journal of Social Science \& Humanities

DOI:

e-ISSN: $2682-8235$

(C) 2018, UCTS Publisher.

Submitted: 2 April 2020

Accepted: 12 May 2020

Published: 30 June 2020

Packaging as one of the proxies of perceived behaviour control, playing a vital role in business practice. Producers who carefully select packaging for their honey products could obtain price premiums and generate greater profits at relatively low costs. Attractive packaging is highly recommended as it increases honey retail prices significantly (Zulail et al., 2014). However, the idea of different countries has different expectations for packaging is widely accepted. For example, most India honey consumers are not comfortable with the bottles and instead wish to have honey in sachets (Santhosh \& Varghese, 2015).

\section{Methodology}

This study was conducted through face-to-face interviews in Penang using a non-probability convenience sampling technique. The questionnaire was pilot-tested and distributed to respondents (Malaysian only) who had either already bought or were interested in purchasing local honey. Descriptive analysis is a display of the frequency of occurrence of each factor and is most commonly used to summarize a set of data. In this study, the survey data on consumers purchase decisions are converted into the actual purchase probabilities. A probit model is employed in the study. Following Studenmund (2017), a general probit model is characterized as follows:

$\left.Z_{i}=\Phi^{-1}\left(\mathrm{P}_{\mathrm{i}}\right)\right]=\beta_{0}+\beta_{1} \mathrm{X}_{i 1}+\ldots+\beta_{\mathrm{n}} \mathrm{X}_{i \mathrm{n}}+\varepsilon$

where $\Phi^{-1}$ refers to the inverse of the normal cumulative distribution function; $\mathrm{P}$ refers to the probability of the respondent purchased local honey over the past 6 months; $X$ is a vector of explanatory variables hypothesized to influence this probability; $\beta$ refers to coefficients of the explanatory variables; $i$ refers to the $i^{\text {th }}$ respondent; $\mathrm{n}$ refers to the $\mathrm{n}^{\text {th }}$ independent variable; $\varepsilon$ refers to stochastic disturbance term. Each explanatory variable is tested with 2 -sided $t$-test with the null hypothesis that $\beta_{\mathrm{n}}$ equals zero, and the alternative hypothesis that $\beta_{\mathrm{n}}$ does not equal zero. The selection of independent variables is based on past research published literature related to the study. The variables used in the model and their measurements are listed in Table 1.

Table 1 Description of Variables

\begin{tabular}{|c|c|}
\hline Variables & Measurement \\
\hline \multicolumn{2}{|l|}{ Dependent variable: } \\
\hline Purchasing decision, $\mathrm{Y}$ & $\begin{array}{l}1 \text { if the respondent purchased local honey over the past } 6 \text { months; } 0 \\
\text { otherwise. }\end{array}$ \\
\hline \multicolumn{2}{|l|}{ Independent variables: } \\
\hline Frequency of honey intake, $\mathrm{X}_{1}$ & $\begin{array}{l}1 \text { if the respondent takes honey at least } 4 \text { days per week; } 0 \\
\text { otherwise. }\end{array}$ \\
\hline Price, $\mathrm{X}_{2}$ & $\begin{array}{l}1 \text { if the respondent feels that reasonable price is an important factor } \\
\text { affecting their decision to purchase local honey; } 0 \text { otherwise. }\end{array}$ \\
\hline Stock availability, $\mathrm{X}_{3}$ & $\begin{array}{l}1 \text { if the respondent feels that the local honey is always available in } \\
\text { the market; } 0 \text { otherwise. }\end{array}$ \\
\hline Distribution availability, $\mathrm{X}_{4}$ & $\begin{array}{l}1 \text { if the respondent can easily get local honey from the market; } 0 \\
\text { otherwise. }\end{array}$ \\
\hline Advertisement, $\mathrm{X}_{5}$ & $\begin{array}{l}1 \text { if the respondent noticed any advertisement of local honey; } 0 \\
\text { otherwise. }\end{array}$ \\
\hline
\end{tabular}


Borneo Journal of Social Science \& Humanities

DOI:

e-ISSN: 2682 - 8235

(C) 2018, UCTS Publisher.

Submitted: 2 April 2020

Accepted: 12 May 2020

Published: 30 June 2020

Company reputation, $\mathrm{X}_{6}$

1 if the respondent only purchases local honey from a certain party (company or bee farm); 0 otherwise.

Packaging, $\mathrm{X}_{7}$

1 if the respondent prefers attractive packaging when purchasing honey; 0 otherwise.

Certification, $\mathrm{X}_{8}$

1 if the respondent prefers to purchase certified local honey; 0 otherwise.

Knowledge of local honey, $\mathrm{X}_{9}$

Medical benefit, $\mathrm{X}_{10}$

1 if the respondent agrees that knowledge of local honey will encourage local honey consumption.

1 if the respondent believes local honey will help reduce the risk of serious diseases or illness; 0 otherwise.

Age, $\mathrm{X}_{11}$

Gender, $\mathrm{X}_{12}$

Years

1 if the respondent is male; 0 otherwise

Income, $\mathrm{X}_{13}$

Marital status, $\mathrm{X}_{14}$

Household size, $\mathrm{X}_{15}$

1 if income is more than RM2500 (> RM2500); 0 otherwise.

1 if the respondent is single; 0 otherwise.

Educational background, $\mathrm{X}_{16}$

Source: Author

Number of household members

1 if the respondent completed tertiary education; 0 otherwise.

\section{Results and Discussion}

Table 2 illustrates the descriptive statistics of those who purchased local honey in the past six months. From a total of 152 respondents who had participated in the survey, 137 respondents (90.13 percent) purchased local honey in the past six months while 15 respondents $(9.87$ percent) did not.

Table 2 Descriptive Statistics of Respondents

\begin{tabular}{llll}
\hline Factors & Categories & Frequency & Percentage (\%) \\
\hline Gender & Male & 66 & 43.42 \\
Age & Female & 86 & 56.58 \\
& $<15$ & 1 & 0.66 \\
& $15-24$ & 21 & 13.82 \\
& $25-34$ & 38 & 25.00 \\
Marital Status & $35-49$ & 48 & 31.58 \\
& $50-64$ & 35 & 23.03 \\
Education Level & $>65$ & 9 & 5.92 \\
& Single & & 37.50 \\
Household members & Married & 57 & 62.50 \\
& Primary and Secondary Education & 53 & 34.87 \\
& Tertiary Education & 74 & 48.68 \\
& Higher Tertiary Education & 25 & 16.45 \\
& 1 & 3 & 1.97 \\
& 2 & 14 & 9.21 \\
& 3 & 24 & 15.79 \\
& 4 & 31 & 20.39 \\
Occupation & 5 & 41 & 26.97 \\
& 6 & 16 & 10.53 \\
& 7 & 11 & 7.24 \\
& 8 & 7 & 4.61 \\
& Government Servants & 5 & 3.29 \\
& Professional & 8 & 5.26 \\
& Housewife & 17 & 11.18 \\
& & 62 & 40.79 \\
& & 23 & 15.13
\end{tabular}


Borneo Journal of Social Science \& Humanities

DOI:

e-ISSN: $2682-8235$

(C) 2018, UCTS Publisher.

Submitted: 2 April 2020

Accepted: 12 May 2020

Published: 30 June 2020

\begin{tabular}{llll} 
& Student & 25 & 16.45 \\
Monthly Income & Retired & 17 & 11.18 \\
& RM0- RM2500 & 84 & 55.26 \\
& RM2500- RM5000 & 23 & 15.13 \\
& RM5000- RM7500 & 23 & 15.13 \\
& RM7500- RM10,000 & 11 & 7.24 \\
& Above RM10,000 & 11 & 7.24 \\
\hline
\end{tabular}

Source: Author

This study investigates the factors affecting the consumers purchasing decisions of local honey using a probit model. The results of the analysis are presented in Tables 3 and 4. The McFadden $\mathrm{R}$-square value for the model is 0.514. Under the testing of Goodness-of-Fit evaluation for binary specification, Andrews statistic is 62.119 with the Chi-square probability is 0.0000 , hence rejects the null hypothesis that the model is invalid, void, amounting to nothing. There are 6 significant variables (stock availability, distribution availability, packaging, knowledge on local honey, income and educational background) out of 16 independent variables that significantly influence the decision of consumers to purchase local honey. The results show that the stock availability and distribution availability of local honey in the local market have a positive relationship with the purchase of local honey. An increase in stock availability of local honey has a positive effect on the decision to purchase local honey. The average marginal effect of stock availability is 0.1085 , implying that the chances of a consumer to purchase local honey over the past 6 months increase by 10.85 percentage points if local honey is consistently available in the market (holding constant other independent variables). The result is supported by Arvanitoyannis \& Krystallis (2006). On the other hand, the average marginal effect of distribution availability is 0.1219 , suggesting that the chances of a consumer to purchase local honey over the past 6 months increase by 12.19 percentage points if local honey can be easily purchased anywhere in the market. The result is in line with the findings of previous studies (Pocol \& Marghitas, 2007; Ványi, Csapó \& Kárpáti, 2011). During the interview, a huge number of respondents stated that they are willing to support the local products and local community, yet they often found difficult to get the local honey. They often go to the outlets or beekeepers or harvesters to get their honey and what frustrated them is the stock is not always available. Sometimes they need to make reservations and they will get the honey only when the stock is ready. This has caused the consumers to opt for imported honey when they have used up their honey and failed to get local honey when they need it. Most of the honey lovers alternate the consumption of local honey and imported honey. When asked whether they consume other local honey available in the market instead of imported honey, they replied that there are limited trustworthy sources of local honey that they know. Online selling of local honey in different platforms like Lazada, Shopee, 11street and others would be an effective way to encounter the challenge of market distribution

Table 3 Result of Probit Model

\begin{tabular}{lllll}
\hline Variable & Coefficient & Standard Error & z-Statistic & P value. \\
\hline Constant & -2.183971 & 1.704168 & -1.281547 & 0.2000 \\
Frequency of honey intake & 1.220822 & 0.682717 & 1.788182 & 0.0737 \\
$\left(\mathbf{X}_{\mathbf{1}}\right)$ & & & & \\
Price $\left(\mathbf{X}_{2}\right)$ & -0.279631 & 0.613976 & -0.455443 & 0.6488 \\
Stock availability $\left(\mathbf{X}_{3}\right)$ & 1.301098 & 0.609892 & 2.133325 & $0.0329^{*}$ \\
Distribution availability $\left(\mathbf{X}_{4}\right)$ & 1.462013 & 0.594001 & 2.461299 & $0.0138^{*}$
\end{tabular}


Borneo Journal of Social Science \& Humanities

DOI:

e-ISSN: $2682-8235$

(C) 2018, UCTS Publisher.

Submitted: 2 April 2020

Accepted: 12 May 2020

Published: 30 June 2020

\begin{tabular}{lllll} 
Advertisement $\left(\mathbf{X}_{\mathbf{5}}\right)$ & 1.283539 & 0.720779 & 1.780765 & 0.0750 \\
Company reputation $\left(\mathbf{X}_{\mathbf{6}}\right)$ & 0.804445 & 0.742364 & 1.083626 & 0.2785 \\
Packaging $\left(\mathbf{X}_{\mathbf{7}}\right)$ & -2.183790 & 0.853204 & -2.559519 & $0.0105^{*}$ \\
Certification $\left(\mathbf{X}_{\mathbf{8}}\right)$ & 0.835508 & 0.671653 & 1.243959 & 0.2135 \\
Knowledge on local honey $\left(\mathbf{X}_{\mathbf{9}}\right)$ & -1.744126 & 0.663699 & -2.627887 & $0.0086^{*}$ \\
Medical benefit $\left(\mathbf{X}_{\mathbf{1 0}}\right)$ & -0.324921 & 0.554554 & -0.585915 & 0.5579 \\
Age $\left(\mathbf{X}_{\mathbf{1 1}}\right)$ & 0.045277 & 0.025976 & 1.743018 & 0.0813 \\
Gender $\left(\mathbf{X}_{\mathbf{1 2}}\right)$ & -0.283124 & 0.550228 & -0.514557 & 0.6069 \\
Income $\left(\mathbf{X}_{\mathbf{1 3}}\right)$ & -1.792057 & 0.629126 & -2.848487 & $0.0044^{*}$ \\
Marital status $\left(\mathbf{X}_{\mathbf{1 4}}\right)$ & 0.218373 & 0.559464 & 0.390326 & 0.6963 \\
Household size $\left(\mathbf{X}_{\mathbf{1 5}}\right)$ & 0.157102 & 0.140727 & 1.116357 & 0.2643 \\
Education $\left(\mathbf{X}_{\mathbf{1 6}}\right)$ & 1.960847 & 0.673941 & 2.909524 & $0.0036^{*}$ \\
\hline
\end{tabular}

* Significant at 5\% level

Source: Author

Table 4 Average Marginal Effect

\begin{tabular}{lll}
\hline Variable & Mean & Standard Deviation \\
\hline Stock availability $\left(\mathbf{X}_{\mathbf{3}}\right)$ & 0.1085 & 0.1651 \\
Distribution availability $\left(\mathbf{X}_{\mathbf{4}}\right)$ & 0.1219 & 0.1856 \\
Packaging $\left(\mathbf{X}_{\mathbf{7}}\right)$ & -0.1821 & 0.2771 \\
Knowledge on local honey $\left(\mathbf{X}_{\mathbf{9}}\right)$ & -0.1454 & 0.2213 \\
Income $\left(\mathbf{X}_{13}\right)$ & -0.1494 & 0.2274 \\
Education $\left(\mathbf{X}_{\mathbf{1 6}}\right)$ & 0.1635 & 0.2488 \\
\hline
\end{tabular}

Source: Author

The results also reveal that packaging and knowledge of local honey are negatively related to the decision to purchase local honey. The average marginal effect of packaging is -0.1821 , indicating that the chances of a consumer to purchase local honey over the past 6 months drop by 18.21 percentage points if the local honey product is attractively packaged; this is similar to the findings of previous studies (Ványi, Csapó \& Kárpáti, 2011; Zulail et al., 2014; Santhosh $\&$ Varghese, 2015). During the interview, many respondents opined that they are aware of attractive packaging of local honey and they feel that an attractive packaging local honey is not worth the money. This implies that honey is less likely to be an "impulse item" and the respondents might not engage in impulse or unplanned purchasing towards local honey (Negara \& Dharmmesta, 2003). Most of the respondents prefer simple packaging for local honey i.e. respondents have fewer expectations on the product appearance. This is probably because many respondents purchase local honey for self-use, hence they are not willing to spend much buying local honey that costs more because of its packaging. The average marginal effect of knowledge on local honey is -0.1454 , indicating that the chances of a consumer to purchase local honey over the past 6 months drop by 14.54 percentage points if a consumer knows local honey. During the interview, the examples of local honey mentioned in the questionnaire are Tualang honey, Gelam honey, Acacia honey, Trigona (Kelulut) honey, and Pineapple honey. These local kinds of honey can be found in different states in Malaysia and each of them contains different nutritional values. Many respondents do not know all the above-mentioned types of honey. In some cases, respondents claim that they have never heard of some of these types of honey. As a result, this finding shows that respondents who know less about local honey have a high tendency to purchase honey over the past 6 months. Some local kinds of honey are not 
Borneo Journal of Social Science \& Humanities

DOI:

e-ISSN: $2682-8235$

(C) 2018, UCTS Publisher.

Submitted: 2 April 2020

Accepted: 12 May 2020

Published: 30 June 2020

popular in the country and respondents only purchase the type(s) of local honey that is familiar, which they possibly heard about by word of mouth. Due to the poor distribution of local honey, only some local kinds of honey are popular or available in certain areas where it is produced. People from other places or states are not able to get these local kinds of honey. Several respondents mentioned that they always purchase the local honey from suburban or rural areas when they visit the place. Some of these respondents originated from suburban or rural areas and are now staying in cities to earn a living; they said that the honey they consumed is bought from their hometown every time they go home to visit their families. Furthermore, some of their friends and colleagues in the cities ask them for a favour to buy the honey.

Consumers' income and educational background are positively related to the decision to purchase local honey. Income is measured as a binary variable where it is coded 1 if the income of the respondent is more than RM 2500. The average marginal effect of consumer income is -0.1494 , meaning that the chances of a consumer to purchase local honey over the past 6 months decrease by 14.94 percentage points if the monthly income of a consumer is more than RM 2500 compared to those with lower income ( $\leq$ RM2500). This contradicts the finding of Roman et al. (2013). This finding shows that local honey is gravitating to become an inferior good because the low-income group has a higher probability to consume it. This finding also reflects a situation that high-incomes group who most probably stay in urban areas or cities face difficulty in reaching the suppliers or producers of local honey because of its poor distribution availability. Therefore, they would purchase imported honey causing a massive influx of imported honey. On the other hand, low-income groups probably stay in the suburban or rural areas that are close to the source of local honey as the beekeepers always produce their honey near the orchards or forests. Consumers' educational background is also positively related to the local honey purchasing decision. The average marginal effect of the consumer educational background is 0.1635 . This suggests that the chances of a consumer to purchase local honey over the past 6 months increase by 16.35 percentage points if a respondent received tertiary education compared to those who do not. This result is in line with previous studies (Yeow et al., 2013; Gyau et al., 2014). This group of respondents has more awareness of the nutritional value of local honey and therefore more likely to purchase it.

\section{Conclusion}

The Malaysian government is committed to developing and promoting the Malaysian local honey in the domestic market as well as in international markets. Yet, the domestic market is still dominated by imported honey, and this has inhibited the development of the local honey industry. Despite the promises and efforts of the Malaysian government, the local honey industry is still facing challenges to reach its potential customers (Arsil, Li \& Bruwer, 2016; Ismail, 2012). This happens could be resulting from the poor marketing strategies even though local honey is one of the favourite foods for the locals and they are willing to support the local community. The study shows that local honey does not only face challenges of stock availability and widespread distribution, but it also faces the challenge of poor knowledge of local honey among the locals. It is because people from other places may not able to reach the local honey produced somewhere else in the country. This problem arises could be attributed to the poor distribution of local honey. Local honey is usually purchased for personal use' therefore a simple packaging is sufficient for its customers. Local honey is also regarded as inferior to imported honey. Hence, to enhance distribution and stock availability, the 
Borneo Journal of Social Science \& Humanities

DOI:

e-ISSN: $2682-8235$

(C) 2018, UCTS Publisher.

Submitted: 2 April 2020

Accepted: 12 May 2020

Published: 30 June 2020

corporation of public authorities (MARDI \& DOA) and private investors is necessary. The Malaysian government should be aware that launching local honey as a superfood at the international level may have limited success if the product does not gain recognition among the locals. The sample used in this study is only limited to Penang Island, thus it may not represent the whole country because consumers from the suburban or rural areas and big cities (Kuala Lumpur and Johore) would probably have different perspectives and expectations. Hence, widen the scope to include rural and urban areas in Malaysia in the future study is highly recommended. In addition, an understanding of consumers' perspectives on imported honey could assist the local honey industry to stay close to the consumers and thus enhance their service and product quality and thereby improve their sales. This study employs a probit model to study the issue; perhaps different approaches (Structural Equation Modelling and Rasch Analysis) could be applied to discover other useful information from different aspects in understanding the development of the local honey industry comprehensively. This study only focuses on the demand of local honey, perhaps a further study on the supply of local honey (e.g., how to increase the brand and image of local honey that consequently increase its value and selling price) should also be considered. Study about local honey producers' (beekeepers and harvesters) perspectives and expectations are of importance for the authorities to improve their current policies and initiatives to invigorate the development of the Malaysian local honey industry.

\section{Acknowledgement}

The authors gratefully acknowledge Universiti Sains Malaysia for the funding from USM short term grant (Account number: 304/PSOSIAL/6313244).

\section{References}

Ajzen, I., (1991). The theory of planned behavior. Organizational Behavior and Human Decision Processes, [online] 50(2), pp.179-211.

Ajzen, I. and Madden, T.J., (1986). Prediction of goal-directed behavior: Attitudes, intentions, and perceived behavioral control. Journal of Experimental Social Psychology, [online] 22(5), pp.453-474.

Anon (2019). FAOSTAT. [online]

Anon (2019). Honey-Information. [online] [Accessed 24 Aug. 2019].

Arsil, P., Li, E. and Bruwer, J., (2016). Using means-end chain analysis to reveal consumers' motivation for buying local foods: An exploratory study. Gadjah Mada International Journal of Business, 18(3), pp.285-300.

Arvanitoyannis, I. and Krystallis, A., (2006). An empirical examination of the determinants of honey consumption in Romania. International Journal of Food Science and Technology, 41(10), pp.1164-1176.

Ciric, M., Ignjatijevic, S. and Cvijanovic, D., (2015). Research of honey consumers' behavior in province of Vojvodina. Ekonomika poljoprivrede, 62(3), pp.627-644.

Cosmina, M., Gallenti, G., Marangon, F. and Troiano, S., (2016). Reprint of "Attitudes towards honey among Italian consumers: A choice experiment approach”. Appetite, 106, pp.110116.

Gyau, A., Akalakou, C., Degrande, A. and Biloso, A., (2014). Determinants of Consumer 
Borneo Journal of Social Science \& Humanities

DOI:

e-ISSN: 2682 - 8235

(C) 2018, UCTS Publisher.

Submitted: 2 April 2020

Accepted: 12 May 2020

Published: 30 June 2020

Preferences for Honey in the Democratic Republic of Congo. Journal of Food Products Marketing, 20(5), pp.476-490.

Handriana, T. and Wisandiko, W.R., (2017). Consumer attitudes toward advertisement and brand, based on the number of endorsers and product involvement: An experimental study. Gadjah Mada International Journal of Business, 19(3), pp.289-306.

Hashim, N.M.H.N., Shah, N.U. and Omar, N.A., (2018). Does counterfeit product quality lead to involvement and purchase intentions? The moderating effects of brand image and social interaction. International Journal of Economics and Management, 12(2), pp.607620.

Ismaiel, S., Kahtani, S. Al, Adgaba, N., Al-Ghamdi, A.A. and Zulail, A., (2014). Factors That Affect Consumption Patterns and Market Demands for Honey in the Kingdom of Saudi Arabia. Food and Nutrition Sciences, 05(17), pp.1725-1737.

Ismail, M.M., (2012). Honey marketing in Malaysia: Agricultural Marketing Issues of Selected Commodities. Universiti Putra Malaysia Press, Serdang, Selangor: UPM Press.

Negara, D.J. and Dharmmesta, B.S., (2003). Normative Moderators Of Impulse Buying Behavior. Gadjah Mada International Journal of Business, 5(1), pp.1-14.

Park, H.S., (2000). Relationships among attitudes and subjective norms: Testing the theory of reasoned action across cultures. Communication Studies, 51(2), pp.162-175.

Pocol, C.B., (2011). Modelling the honey consumption behaviour in Romania by using sociodemographic determinants. African Journal of Agricultural Research, 6(17), pp.40694080 .

Pocol, C.B., (2012). Consumer preferences for different honey varieties in the North West Region of Romania. Lucrari Stiintifice, Universitatea de Stiinte Agricole Si Medicina Veterinara 'Ion Ionescu de la Brad' Iasi, Seria Agronomie, [online] 55(2), pp.263-266.

Pocol, C.B. and Bolboacă, S.D., (2013). Perceptions and trends related to the consumption of honey: A case study of North-West Romania. International Journal of Consumer Studies, 37(6), pp.642-649.

Pocol, C.B. and Marghitas, L.A., (2007). Market study about honey consumption in Romania. Bulletin of University of Agricultural Sciences and Veterinary Medicine Cluj-Napoca. Animal Science and Biotechnologies, [online] 64(1-2), pp.398-401.

Roman, A., Popiela-Pleban, E. and Kozak, M., (2013). Factors influencing consumer behavior relating to the purchasing of honey part 1 . The buying process and the level of consumption. Journal of Apicultural Science, 57(2), pp.159-172.

Roman, A., Popiela-Pleban, E., Kozak, M. and Roman, K., (2013). Factors influencing consumer behavior relating to the purchase of honey part 2. Product quality and packaging. Journal of Apicultural Science, 57(2), pp.175-185.

Santhosh, J. and Varghese, A., (2015). A study on consumer buying behaviour on honey in Kerala with special reference to Kollam district. EPRA International Journal of Economic and Business Review, 3(10), pp.185-187.

Studenmund, A.H., (2017). A practical guide to using econometrics. [online] Pearson Education Limited.

The Star, O., (2016). Sweet profit in stingless bee farms. The Star Online. [online]

Ványi, G.Á., Csapó, Z. and Kárpáti, L., (2011). Evaluation of consumers' honey purchase habits in Hungary. Journal of Food Products Marketing, 17(2-3), pp.227-240.

Yeow, S., Chin, S., Yeow, J. and Tan, K., (2013). Consumer Purchase Intentions and Honey Related Products. Journal of Marketing Research and Case Studies, [online] 2013, pp.1- 
Borneo Journal of Social Science \& Humanities

DOI:

e-ISSN: $2682-8235$

(C) 2018, UCTS Publisher.

Submitted: 2 April 2020

Accepted: 12 May 2020

Published: 30 June 2020

15.

Zulail, A., Ismaiel, S., Kahtani, S. Al, Al-Ghamdi, A.A. and Adgaba, N., (2014). Qualitative Factors Affecting the Price and Demand of Honey in Saudi Arabia. Australian Journal of Basic and Applied Sciences, [online] 8(810), pp.199-206. 